MAJOROS ANTAL'1, DR. KOZMA MIHÁLY², KISS CSABA ${ }^{3}$

\title{
VITAMINOK ÉLETTANI HATÁSAI ÉS VITAMINSZEDÉSI SZOKÁSOK
}

\author{
'Eszterházy Károly Egyetem, Állattani Tanszék, Biológia BSc hallgató, \\ 3300 Eger, Leányka út. 6. \\ *email: latna.sorojam@gmail.com \\ ${ }^{2}$ Magyar Igazságügyi Szakértői Kamara, 3300 Eger, Szarvas G. u. 3. \\ ${ }^{3}$ Eszterházy Károly Egyetem, TTK Biológiai Intézet, Állattani Tanszék, \\ 3300 Eger, Leányka u. 6.
}

\section{Összefoglaló}

Kutatásunk középpontjában a C- illetve D-vitaminok élettani hatásai, és ezen vitaminok különböző korcsoportok általi szedési szokásainak felmérése áll. Először néhány fontosabb, az említett vitaminokra vonatkozó élettani hatás kerül megemlítésre, amelyek különféle kutatásokkal vannak igazolva. A továbbiakban pedig saját kutatásunk bemutatása kerül előtérbe, amit Eger és környező kistérségében élő emberek bevonásával végeztünk 2019 márciusától. A rendelkezésre álló 201 darab kitöltött kérdőív kiértékelését követően a kitöltők C- és D-vitamin szedési szokásainak mennyiségéről és rendszerességéről kapunk információt, valamint hogy a C-vitamin-szedés és vesekő kialakulásának kockázata között van-e összefüggés.

Elfogadva: 2020. 06. 07.

Elektronikusan megjelent: 2020. 


\title{
ANTAL MAJOROS', DR. MIHÁLY KOZMA², CSABA KISS ${ }^{3}$
}

\section{VITAMINOK ÉLETTANI HATÁSAI ÉS VITAMINSZEDÉSI SZOKÁSOK}

'Eszterházy Károly Egyetem, Állattani Tanszék, Biológia BSc hallgató, 3300 Eger, Leányka út. 6.

*email: latna.sorojam@gmail.com

2Magyar lgazságügyi Szakértői Kamara, 3300 Eger, Szarvas G. u. 3. ${ }^{3}$ Eszterházy Károly Egyetem, TTK Biológiai Intézet, Állattani Tanszék, 3300 Eger, Leányka u. 6.

\begin{abstract}
Our research focuses on the physiological effects of vitamins $C$ and $D$ and their intake by different agegroups. First, some of the more important physiological effects of these vitamins are mentioned, which have been proven by various studies. In the following part, we are presenting our own research, what has been started in March 2019.We involved some people from Eger and its surrounding micro-region. After evaluating the available 201 completed questionnaires, we get informations about the amount and frequency of vitamin $C$ and $D$ intake and is there a correlation between vitamin $C$ intake and the risk of developing kidneystones?
\end{abstract}

Accepted: 07. 06. 2020.

Published online: 2020. 


\section{Bevezetés}

\section{C-vitamin}

A természetes antioxidánsok közé soroljuk az A-, C-, E-, K-vitaminokat, melyek variábilis módon képesek hatni a lipidperoxidáció különböző fázisaiban. Közülük a C-vitamin a szabad gyökök elleni védelemben, illetve a hidrogénperoxidok keletkezésének gátlásában játszik fontos szerepet. Az aszkorbinsavként is ismert redukálószer eléggé instabil, így könnyen elvesztheti hidrogénatomjait, mely által képes megkötni a szabad gyököket (Jopp, 2008).

Mik is azok a szabad gyökök? Olyan atomok, illetve molekulák, amelyeknek párosítatlan elektronjuk, illetve betöltetlen elektronpályájuk van. Rendkívül reakcióképesek, más molekulák elektronjait felvéve oxidálják és módosítják a sejteket. Az oxigén szabad gyököket a leggyakoribb szabad gyökök közé soroljuk. Az endoplazmatikus retikulum és a mitokondrium múködése során a molekuláris oxigén vízzé redukálása egymást követő egyelektronos redukciós lépésekben történik. Ha a folyamat megakad, reaktív oxigénszármazékok (szuperoxid, hidrogénperoxid, hidroxil szabad gyök) keletkeznek. Ezek a szabad gyökök károsítják a fehérjéket, génmódosításokat, illetve nem kívánt génszakaszok aktiválását okozhatják, valamint enzimeket hatástalaníthatnak. Lassítják, esetleg leállítják a sejtek anyagcseréjét, amelyek segédkeznek a sejtöregedési folyamatokban (SzeBERÉnYı, 2014).

Az aszkorbinsav nagy szerepet játszik a sejtek védelmében is. Az immunsejtek esetében a fehérvérsejtek C-vitamin koncentrációja akár negyvenszer nagyobb lehet más sejtek plazmájában mérhető szintjétől, vagyis ezeknek a sejteknek kifejezetten nagy a C-vitamin igényük a kórokozók elleni harcban. C-vitamin hiányakor sokkal nagyobb mértékben lehet fogékony a szervezet a fertőzésekkel szemben, emiatt már a betegség korai szakaszában ajánlott a napi C-vitamin-mennyiség növelése.

Egy ember C-vitamin igényét rendkívül sok tényező befolyásolhatja: életkor, nem, testsúly, egészségi állapot, életmód, testmozgás, egészséges táplálkozás, terhesség, anyagcsere, dohányzás, alkoholfogyasztás, stressz, környezeti tényezők, génkészlet. Az RDA (Ajánlott Napi Tápanyagbevitel) egy olyan minimális mennyiségi javaslat, ami ezeket a tényezőket nem veszi figyelembe. A C-vitamin RDA ajánlása napi 60-90 mg egy felnőtt ember esetében, amit ha hosszú távon nem juttatunk be a szervezetbe, az kimerül, és bekövetkezik a skorbut. A C-vitamin napi igényét befolyásoló tényezők további C-vitamint emésztenek fel, és mivel ezek egyénenként változnak, szinte lehetetlen milligrammra pontosan meghatározni (Jopp, 2009). 


\section{D-vitamin}

A D3-vitamin, vagy más néven kolekalciferol, egy olyan szteránvázas vegyület, amely napfény hatására a bőrünkben szintetizálódik, de táplálékkal is bekerülhet a szervezetünkbe. Az előanyag a bőrsejtekben lévő 7-dehidrokoleszterin (D3-provitamin), amely abszorbeálja az UV-B-sugárzást, melynek következtében elsőnek D3-previtaminná alakul, majd hő hatására a szerkezete megváltozik, és létrejön a D-vitamin. A bőrsejtekből a vérbe kerül, és két lépésben aktiválódik, és onnantól már mint hormon funkcionál (HoLIck, 2012). Az aktiválódás első lépcsőfoka a májban történik, ahol a D-vitamin hidroxilálódása következtében 25-hidroxi-D-vitamin képződik. Ezt követően elszállítódik a vesébe, illetve más szövetek sejtjeibe, ahol 1-alfa-hidroxilációval 1,25-dihidroxi-D-vitaminná alakul. Az immáron aktív, hormonális hatással bíró $D$-vitamin a vesében a kalcium anyagcseréjében játszik elengedhetetlen szerepet, valamint más szövetek sejtjeiben autokrin-parakrin hatást lát el (BALOGH, 2016). Az aktív D-vitamin serkenti a kalcium és a foszfát felszívódását a belekből, így hozzájárul a csontok épségéhez is (Jopp, 2006).

A D-vitamin klasszikus, hormonális hatásai az ásványi anyagcseréhez és a csontváz egészségéhez kapcsolódnak. A D-vitamin javítja a bélben a kalcium és foszfát felszívódását, serkenti az osteoclast differenciálódását és a kalcium reabszorpcióját a csontokból, elősegíti a csont mátrixának mineralizációját (PRIETL, 2013). Németországban az emberek 90\%-a, Magyarországon 50\%-a (Jopp, 2006) és a világ lakosságának is közel fele D-vitamin-hiányos (BALOGH, 2016). Az egyik legismertebb hiánybetegsége az angolkór, amely ma már nem túl gyakori, de még mindig előfordul néhány kevésbé fejlett országban. Az angolkór a fejlődésben lévő csontváz megbetegedése, amely jellemzően gyermekkorban fordul elő. Elsősorban a csontok (többnyire az alsó végtagok, a mellkas és a koponya) mészhiányára utal, és a csont törékenysége és eldeformálódása jellemzi. Kialakulása a helytelen táplálkozás vagy a napfény hiánya következtében jöhet létre. Egy feltételezés szerint a genetikai tényezők, a napfény és a bőr pigmentációja közötti különbségek mellett a vashiány is befolyásolhatja a D-vitamin viselkedését a bőrben vagy a bélben (WHARTON, 2003).

A WHO (World Health Organization) a 10 legfenyegetőbb betegség közé sorolja a csontritkulást. A csontritkulás a csontozat ásványianyag-veszteségét jelenti, aminek következtében a csonttömeg jelentősen csökken. Kóros D-vitamin-hiányról $20 \mathrm{ng} / \mathrm{ml}$ vagy kevesebb vérben lévő koncentráció esetén beszélünk; 21-29 ng/ml enyhe D-vitamin-hiánynak számít; az optimális D-vitamin-szint 30-100 ng/ml; ugyanakkor $150 \mathrm{ng} / \mathrm{ml}$ felett már D-vitamintoxicitásról beszélünk (Holick, 2012).

A Michigan State University orvosai által összegzett kutatások azt mutatták, hogy a D-vitamin meghosszabbíthatja a rákos betegek élettartamát (HAYKAL, 2019). Az eredményeket az Amerikai Klinikai Onkológiai Társaság éves ülésén, 2019. június 3-án mutatták be, ahol azt közölték, hogy a D-vitamin az egészséges csontokhoz való pozitív élettani hozzájáruláson túl más jelentős előnyökkel 
is jár. A kutatók több mint 79000 páciens betegségmegelőzéssel kapcsolatos adatait vizsgálták meg, amelyekben a résztvevők véletlenszerüen sorsolva D-vitamint vagy placebót kaptak legalább három éven át. A D-vitamin jelentősen befolyásolta a rákos betegek élettartamát, viszont nem találtak bizonyítékot arra vonatkozólag, hogy védelmet nyújtana a rákos megbetegedések ellen. Noha ezek az eredmények ígéretesnek bizonyulnak, a tanulmány kitért arra is, hogy a bevitt vitamin pontos mennyisége és a vérben szükséges szintje még nem ismert. Nem egyértelmű, mennyi ideig hosszabbítja meg a D-vitamin az élettartamot, és hogy ezt miért is eredményezi. Azonban az eddigi eredmények elég bizonyítékot szolgáltattak arra, hogy ösztönözze az orvosokat, különösképpen az onkológusokat, a D-vitamin emelt szintű bevitelére a betegek számára.

A napi D-vitamin-szükségeltünket legegyszerübben a természetes napfény segítségével is pótolhatjuk. Viszont milyen más hatásokkal járhat a D-vitamin ajánlott mennyiségtől eltérő bevitele? Egy, az 1950-es évektől napjainkig tartó kutatásban kimutatták, hogy Amerika délkeleti részein kevesebb a vastagbél-, az emlő-, a petefészek- és a prosztatarák, ami magyarázat lehet arra, hogy a napfény által bőrben képződő $D$-vitamin csökkenti a rák kialakulásának esélyét (GRANT, 2011). Egy másik, a Helsinki HeartStudy 19 ezer mintát vizsgáló kutatásában a <40 nmol/l szérum D-vitamin-szintnél 1,7-szer, fiataloknál 3,5-ször nagyobb volt a prosztatarák kialakulásának az esélye, mint $>40 \mathrm{nmol} / \mathrm{l}$ szérumszintnél (TuoHIMAA, 2008). A Women's Health Initiative nyolc éven át tartó kutatása ugyancsak azt állapította meg, hogy a <30 nmol/l szérumszintnél 253\%-kal nagyobb volt a vastagbélrákkockázat, mint optimális ellátottság esetén (LENZ, 2009).

Normál, egészséges felnőttek számára a Health Canada összesen 600 nemzetközi egység (NE), 70 éves kor felett pedig 800 NE napi D-vitamin bevitelét javasolja (BURT, 2019). 2013. augusztus és 2017. december vége között végzett kutatásuk során 3 párhuzamos csoportot vizsgáltak (400, 4000 és 10000 NE D-vitamin napi adag mellett). Az önkéntesek csontsűrűségét és -szilárdságát a csukló- és a bokacsontok esetében új, nagy felbontású számítógépes tomográfiai vizsgálat $(\mathrm{CT})$ segítségével, XtremeCT néven mérték. A D-vitamin és a kalcium szintjének felmérése érdekében a kutatók éhgyomri vérvételt, valamint vizeletgyűjtést is végeztek párhuzamosan. A kutatás során megállapították, hogy a bevitt D-vitamin-mennyiségtől függetlenül az idő elteltével lassan csökkent a csontásványi anyagtartalma: a hároméves időszakban 1,4\%-kal a $400 \mathrm{NE}$ csoportban, 2,6\%-kal a $4000 \mathrm{NE}$ csoportban és 3,6\%-kal a 10000 NE csoportban. A következtetés az volt, hogy az előrejelzésekkel ellentétben a Health Canada vagy az Osteoporosis Canada által ajánlottaknál magasabb dózisú D-vitamin-kiegészítés nincs összefüggésben a csontsűrűséggel, vagy annak a növekedésével. Ehelyett az XtremeCT-vel a csontsűrűség csökkenését detektálták, a legnagyobb mértékű leépülés pedig épp a napi 10000 NE csoportban fordult elő. 


\section{Anyag és módszer}

Kérdőíves kutatásomat Eger és környező kistérségében élő emberek bevonásával végeztem 2019 márciusától kezdve. A mintavétel három korcsoportban zajlott, 15-19; 20-25; és 40-45 éves emberek között.

A minta elemszáma 239 fő volt, a végső elemszám 201 fő lett. A kettő érték közötti differencia az értékelhetetlen kitöltésekből adódott. A kiosztott kérdőívek kitöltésének visszautasítására nem volt példa, így a válaszadási arány 84,1\% lett. A felmérést önkitöltéses kérdőívek segítségével végeztem. A válaszadók részletes tájékoztatást kaptak a kérdőívről, illetve arról, hogy a kérdőív kitöltése teljesen anonim, azokat harmadik személy rendelkezésére nem bocsátjuk ki, valamint a kitöltők beazonosítására utólag sem lesz lehetőség.

A kérdőívek kitöltése a 15-19 év közötti korcsoportban tanórai keretek között történt, a pedagógusok segítségével, az egri Dobó István Gimnáziumban. A 20-25 és 40-45 év közötti korcsoport megkérdezése az Eszterházy Károly Egyetem területén véletlenszerüen, illetve internetes felmérések során történt.

A kérdőív első részében a kérdések a különböző szocio-demográfiai változókra (pl. nemre, életkorra, súlyra, lakóhelyre) vonatkoztak. A további részek a dohányzással, alkoholfogyasztással és sportolással kapcsolatos tényezőkre terjedt ki. Ezek után a vitaminszedési szokásokra kérdeztünk rá, hogy milyen vitamint, milyen gyakran szednek és milyen mennyiségben.

Az adatok elemzését, kiértékelését és grafikus ábrázolását R-statisztikai környezetben végeztem (TEAM $R$, 2015). A kérdésekre kapott válaszokat százalékos arányban tortadiagramokon szemléltetem, ezzel az egyes változók közötti kapcsolatok irányáról kaptunk információt.

Két faktor összehasonlítása esetén homogenitásvizsgálatot alkalmaztam, a hozzájuk kapcsolódó szignifikanciaszinteket khi-négyzet-próbával számoltam ki.

Háromfaktoros összehasonlítások alkalmával az R-statisztikai környezetben vcd (Meyer, Zeileisés Hornik, 2006), grid (MurRell, 2002), coin (Hothorn, 2006) feladatspecifikus csomagokat használtam. A (hozzávetőleges) permutációs eloszlásban téglalapos megjelenítést alkalmaztam, ahol egy téglalap egy adategységet jelölt, területe pedig arányos volt az értékpárok gyakoriságával. Ahol a program szignifikáns értéket talált, ott a sötétszürke szín pozitív (százalékosan nagyobb előfordulás), a legvilágosabb szürke szín pedig negatív (százalékosan kevesebbszer fordul elő) értéket jelöl.

\section{Eredmények}

A C-vitamin-szedés korcsoportonkénti eloszlásakor szignifikáns eredményt kaptam (p-érték = 0.00228). Az 1., 2., és 3. ábrákon látható, hogy a kor növekedésével arányosan növekszik a C-vitamin-bevitel rendszeressége is.

A 3. korcsoportban százalékos arányban duplaannyian (56\%) szednek rendszeresen C-vitamint, mint a másik két csoportban (24\% - 30\%), viszont csak 
feleannyian időszakosan (18\%). A C-vitamint nem szedők aránya megközelítőleg azonos mind a három korcsoportban, illetve a 2. és 3. csoportban azonos érték (16\% - 16\%) jött ki az alkalmanként (amikor eszébe jut) szedők között.

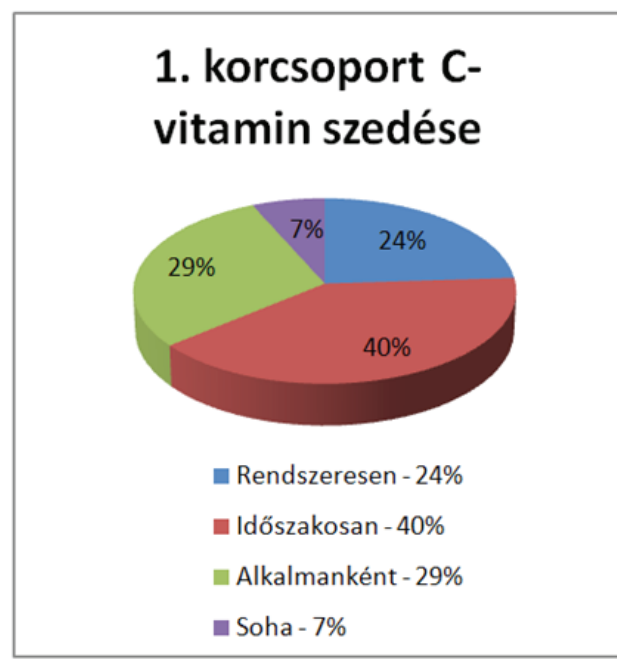

1. ábra: 14-19 év közöttiek C-vitamin szedési szokásaik gyakorisága

\section{2. korcsoport C- vitamin szedése}

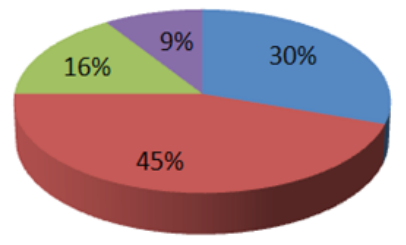

- Rendszeresen - 30

- Időszakosan- $45 \%$

Alkalmanként - 16\%

- Soha- $9 \%$

2. ábra: 20-25 év közöttiek C-vitamin szedési szokásaik gyakorisága

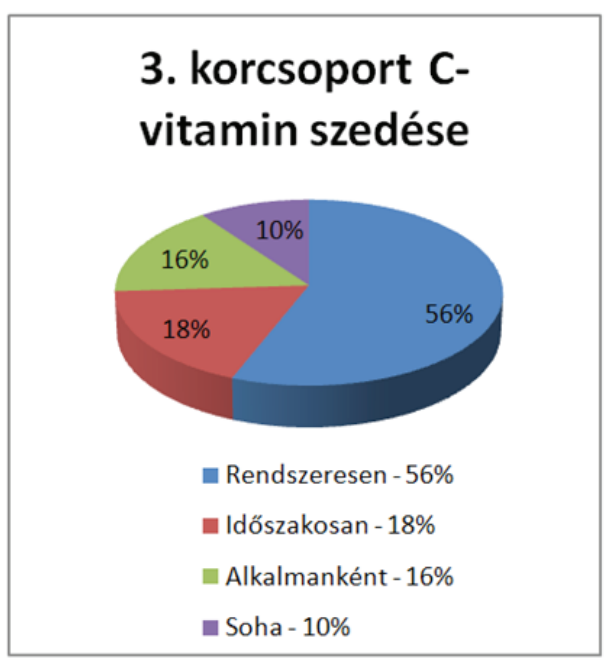

3. ábra: 40-45 év közöttiek C-vitamin szedési szokásaik gyakorisága

A 40 év felettieknél fokozódik a csontok ásványianyag tartalmának vesztesége, ezért nekik különösen figyelniük kell a D-vitamin megfelelő mennyiségú rendszeres pótlására. Véleményem szerint ez a magyarázata annak, hogy a 4., 5. és 6. ábrán jól látható, hogy a kor előrehaladtával csökken azoknak az aránya, akik egyáltalán nem szednek $D$-vitamint. A résztvevők közül a $D$-vitamin 
rendszeres fogyasztása a 2. korcsoportban (5. ábra) volt a legkevésbé jellemző, azonban azok aránya, akik a D-vitamint időszakosan szedik, itt a legmagasabb.

A 3. korcsoportban (6. ábra) a legjellemzőbb a D-vitamin rendszeres szedése. A homogenitásvizsgálat során eredményként kapott $p$-érték $=0.008969$ szignifikanciaszint azt mutatja, hogy a vizsgált korcsoportok D-vitamin szedési szokásai között van összefüggés.

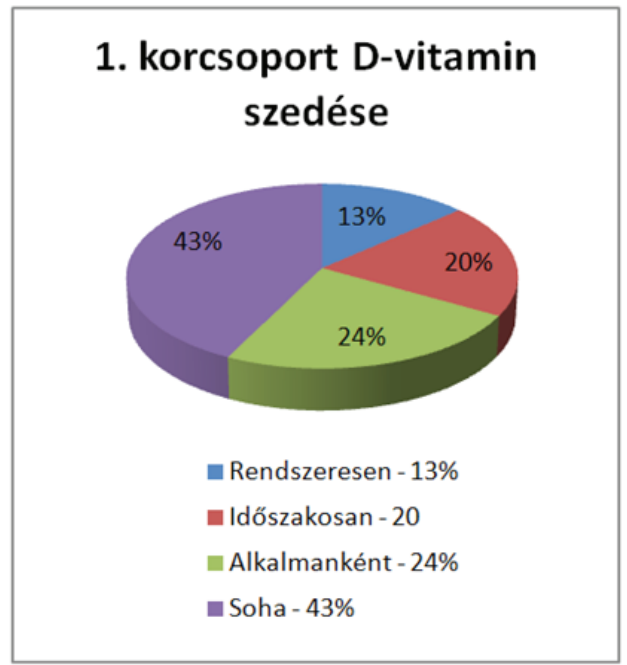

4. ábra: 14-19 év közöttiek D-vitamin szedési szokásaik gyakorisága

\section{2. korcsoport D-vitamin} szedése

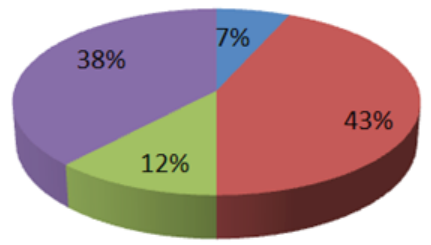

- Rendszeresen - 7\%

- Időszakosan-43\%

- Alkalmanként - 12\%

- Soha - $38 \%$

5. ábra: 20-25 év közöttiek D-vitamin szedési szokásaik gyakorisága

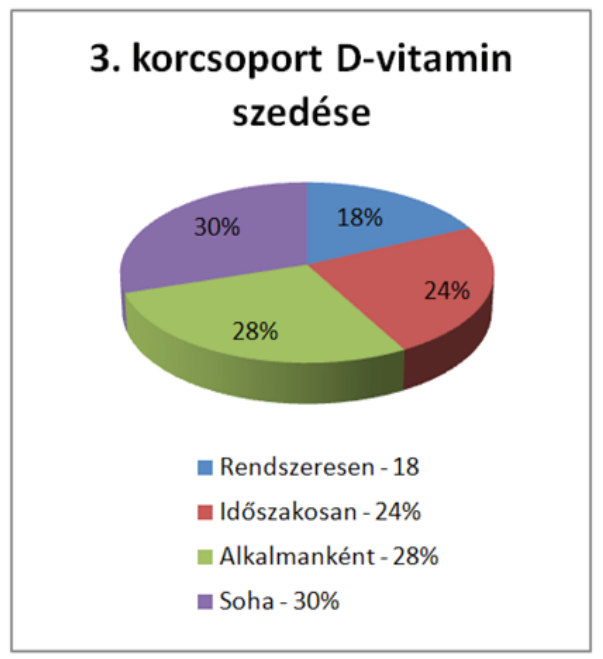

6. ábra: 40-45 év közöttiek D-vitamin szedési szokásaik gyakorisága 
A beszedett C-vitamin-mennyiséget (mg) és a vesekő előfordulását a 7. és a 8. ábrán hasonlítottuk össze. A homogenitásvizsgálat során szignifikáns értéket kaptam ( $p$-érték = 0.04962), ami a két faktor összefüggésére utal.

A változók közötti kapcsolatok irányából kiderül, hogy azoknál a válaszadóknál, akiknél már előfordult vesekő, nagyobb arányban jellemző az 1000-1500 mg vagy annál több C-vitamin szedése (62\%). Ugyanakkor, akiknek nem volt veseköve, ezek aránya mindössze csak $34 \%$ volt.

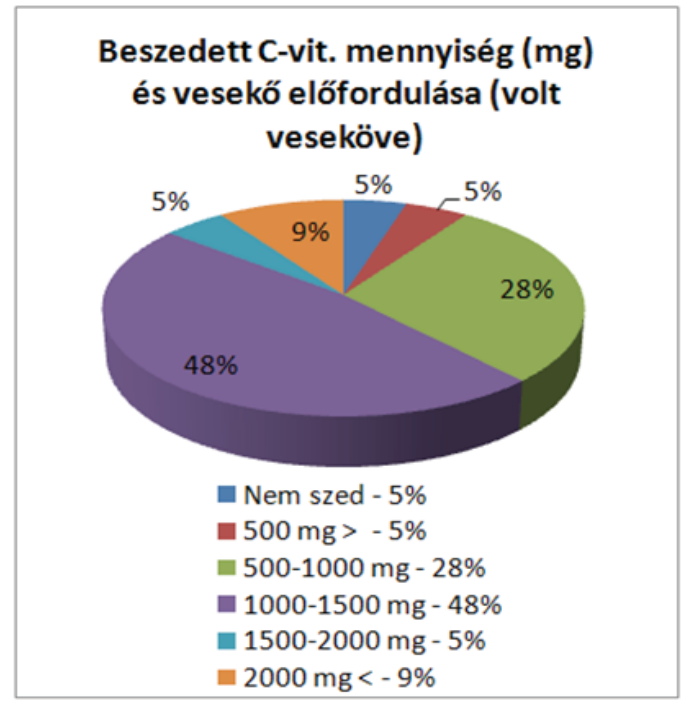

7. ábra - Beszedett C-vitamin mennyiség (mg) és azok, akiknél előfordult már vesekő

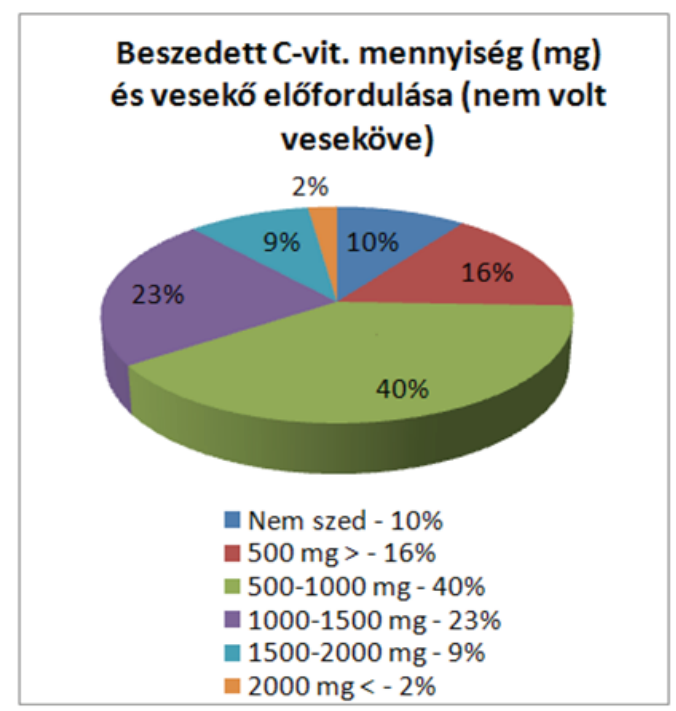

8. ábra: Beszedett C-vitamin mennyiség (mg) és azok, akiknek nem volt veseköve 
$A$ válaszadók $C$-vitamin szedési rendszerességét ( $S=S o h a, A=A l k a l m a n k e ́ n t$, I=Időszakosan, R=Rendszeresen) és a „volt-e már veseköve?" kérdésre kapott (igen, nem) válaszokat korcsoportonként egy mozaikos ábrázolásban összegeztük a 9. ábrán. Az ábrán látható sötétszürke téglalap arra utal, hogy a C-vitamint rendszeresen szedő 40-45 év közöttieknél nagyobb arányban fordult elő vesekő. A világosszürke téglalap viszont azt jelzi, hogy érdekes módon azoknál a 40-45 év közötti válaszadóknál fordult elő legkevesebbé vesekő, akik csak időszakosan (pl. téli időszakban) szedtek C-vitamint (9. ábra).

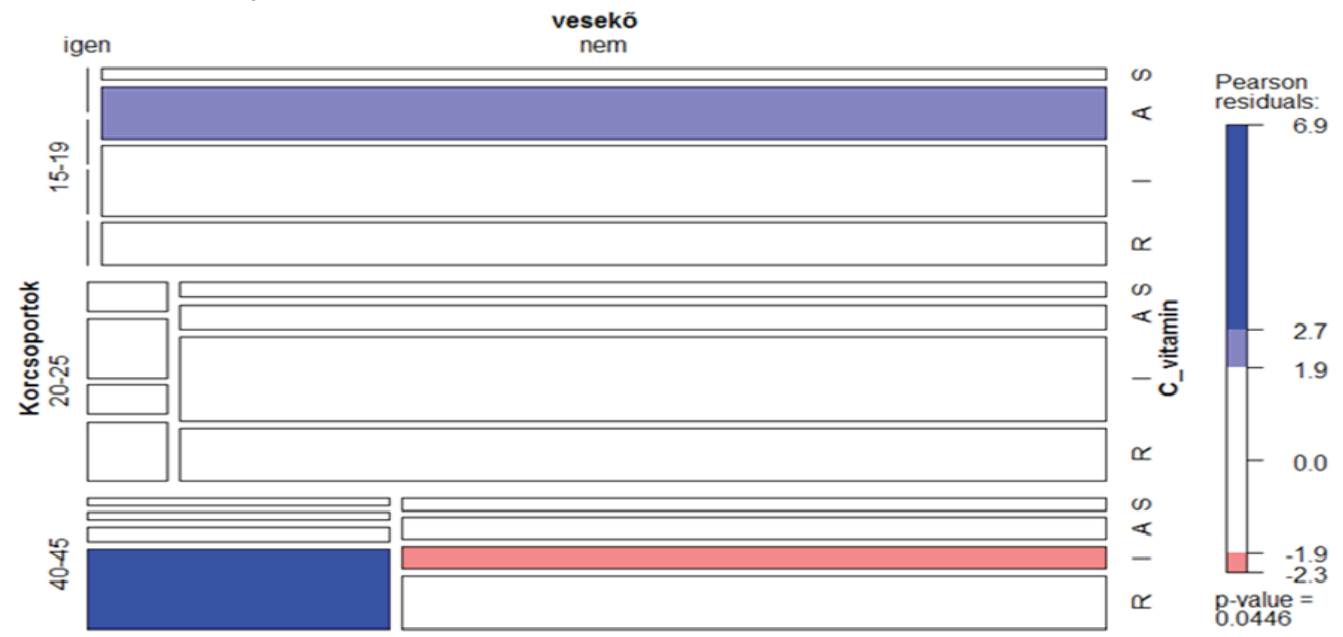

9. ábra: C-vitamin szedési szokások korcsoportok szerinti felosztása vesekő előfordulása szempontjából

A sportolók és nem sportolók C-, illetve D-vitamin szedésének mozaikos ábrázolásakor szintén szignifikáns eredményt ( $p$-érték $=0.0016)$ kaptam arra nézve, hogy van összefüggés a kérdőívek kitöltésében résztvevő emberek sportolási és vitaminszedési szokásai között (10. ábra). A kutatásban azokat az embereket tekintettem sportolóknak, akik hetente legalább két alkalommal sportolnak. A három faktor összehasonlításakor azt az eredményt kaptam, hogy a válaszadók köreiben inkább a vitaminok időszakos szedése a jellemzőbb, mint a rendszeres.

Megfigyelhetjük, hogy azok a válaszadók, akik rendszeresen sportolnak és rendszeresen szednek C-vitamint (sötétszürke téglalap), százalékos arányaiban rendszeresebben fogyasztanak $D$-vitamint is. A nem sportoló, viszont C-vitamint rendszeresen fogyasztó válaszadók kategóriájában (legvilágosabb szürke téglalap) százalékosan kevesebb azoknak az aránya, akik sohasem szednek D-vitamint. A C-vitamint soha nem szedők között nagyobb az aránya azoknak a válaszadóknak, akik nem sportolnak, és soha sem szednek D-vitamint (legfelső sötétszürke téglalap; 10. ábra). 


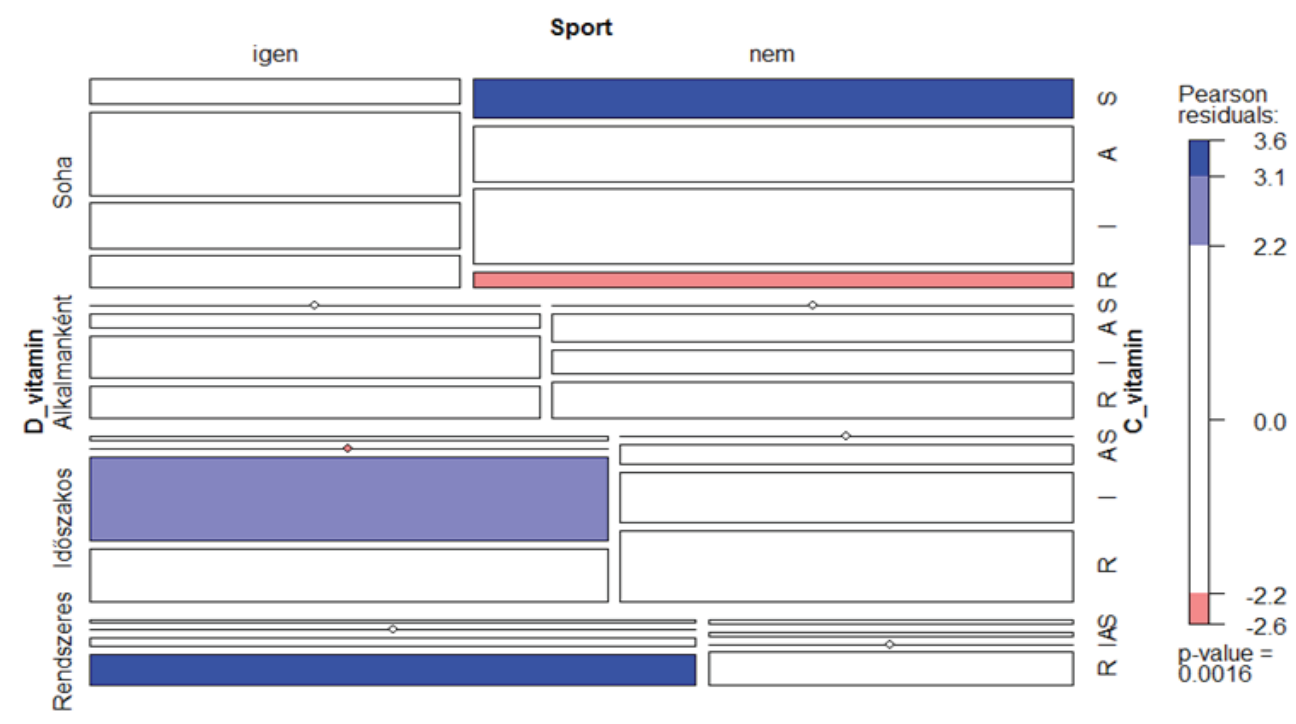

10. ábra - C-vitamin szedési szokások D-vitamin fogyasztás szerinti felosztása a sportolást illetôleg

\section{Összefoglalás}

Ma már több mint 13 vitamint ismerünk, és bár tudjuk, hogy nem mindegyik vitamin tartozik az aminok közé, a szó első fele viszont nagyon is találó, hiszen a vitaminok olyan esszenciális szerves vegyületek, amit az emberi szervezet nem, vagy nem elegendő mennyiségben képes elóállítani. A tudomány fejlődésének köszönhetően egymás után tudunk meg újabb és újabb információkat a vitaminokról és hatásukról. A médiának köszönhetően egyre több ember szed táplálékkiegészítőket életminőségük javulása vagy fenntartásának érdekében (MüHLEIB, 2003). Az embereknek elégséges mennyiségben kell pótolniuk a vitaminokat a megfelelő életminőség fenntartása érdekében. Fontos különbséget tenni a minimális szükséglet és az optimális mennyiség között. A minimális szükségletet táplálkozás során ugyan lehet fedezni, de ez a mennyiség csak arra elegendő, hogy ne jelentkezzenek a hiánytünetek. Optimális vitaminellátottság esetén a szervezet képes kényelmesen felhasználni a számára szükséges vitaminokat a megfelelő szervi funkciókban (Jopp, 2008). Egy ember vitaminigényét rendkívül sok tényező befolyásolhatja, így szinte lehetetlen meghatározni azt a pontos mennyiséget, ami fedezi a napi szükségletet.

A C-vitamin-szedésnél a korcsoportonkénti összehasonlításban szignifikáns eredményt kaptam (1., 2., 3. ábra) arra vonatkozólag, hogy az életkor előrehaladtával növekszik a C-vitamin-bevitel rendszeressége. A 3. korcsoportban (40-45 év közöttiek) százalékos arányban duplaannyian szednek rendszeresen C-vitamint, mint a másik két korcsoportban (14-19 és 20-25 év közöttiek). Tehát az előbb említettek alapján az a következtetés vonható le, hogy az idősebbekre 
(40-45 év közöttiek) jellemzőbbek a betegségek prevenciója iránti törekvések, amiket többek között rendszeresebb C-vitamin-fogyasztással igyekeznek elérni.

A D-vitamin-szedésnél a korcsoportonkénti összehasonlításban ismételten szignifikáns eredményt kaptam (4., 5., 6. ábra). A résztvevők közül a D-vitamin rendszeres fogyasztása a 2. korcsoportban volt a legkevésbé jellemző, azonban egyben a legmagasabb is, akik a D-vitamint csak időszakosan szedik. Az eredmények azt mutatják, hogy a kor előrehaladtával a D-vitamint egyáltalán nem szedők százalékos aránya csökken, vagyis az idősebb válaszadók körében többen döntöttek úgy, hogy pótolják a D-vitamint valamilyen vitaminkészítmény formájában.

Azoknál a válaszadóknál, akiknél már egyszer előfordult vesekő, kortól függetlenül nagyobb arányban jellemző az 1000-1500 mg vagy annál több C-vitamin szedése (62\%), míg akiknek még sosem volt, azok aránya mindössze 34\% (7., 8. ábra). A 3. korcsoportban (40-45 év közöttiek) gyakrabban fordult elő vesekő, főleg azoknál a válaszadóknál, akik rendszeresebben és nagyobb mennyiségben fogyasztanak C-vitamin-készítményeket (9. ábra). Kutatásom során hasonló eredményeket kaptam, mint Thomas és munkatársai (2013), ahol több ezer 40 év feletti svéd férfit vizsgáltak egy évtizeden át. A résztvevőket két részre osztották, ahol az egyik csoport nem szedett semmiféle táplálékkiegészítőt, a másik csoport viszont igen (C-vitamin). Az eredményeik alapján kiderült, hogy a C-vitamint szedőknél a vesekő képződésének veszélye nagyobb volt, mint a nem szedők esetében. Összességében a kérdőívet kitöltők válaszai alapján arra lehet következtetni, hogy a C-vitamin nagyobb mennyiségú bevitele során fokozódik a vesekő kialakulásának kockázata.

A sportolók és nem sportolók C-, illetve D-vitamin szedési szokásainak kiértékelése során (10. ábra) a válaszadók köreiben inkább a vitaminok időszakos szedése volt a leggyakoribb. Megfigyelhetjük, hogy azok a válaszadók, akik rendszeresen (legalább kétszer egy héten) sportolnak, és emellett rendszeresen szednek C-vitamint, nagyobb arányban fogyasztanak D-vitamint is. A nem sportolók között viszont a C-vitamint rendszeresen fogyasztó személyek kategóriájában kevesebb volt azoknak az aránya, akik sohasem szednek D-vitamint. Ugyanakkor a sportolók körében népszerübb a C- és D-vitamin együttes szedése, ami az egészséges életmódra való törekvésre enged következtetni. Továbbá, a sportolók életvitelük alapján szervezetük fokozott igénybevétele miatti vitaminveszteségüket rendszeresebben és sokoldalúbban igyekeznek pótolni. 


\section{Köszönetnyilvánítás}

Köszönettel tartozom témavezetőmnek, dr. Kozma Mihálynak mindazért a segítségért, amit a kutatás során nyújtott, valamint hogy lehetőséget teremtett számomra egy ilyen érdekes és fontos témában való részvételért. Külön köszönettel tartozom dr. Emri Zsuzsannának, dr. Antal Károlynak és Kiss Csabának, hogy rendkívül sok segítséget nyújtottak az adatok kiértékelésében.

Továbbá szeretném megköszönni mindazoknak, akik kitöltötték a kérdőívet és válaszaikkal hozzájárultak a dolgozatom elkészüléséhez.

\section{Felhasznált Irodalom}

Balogh, S., Lakatos P., TaKÁcs I. (2016). A D-vitamin-anyagcsere és a policisztás ovarium szindróma. Orvostovábbképző Szemle, 23. 35-40.

Burt, L. A., Billington, E. O., Rose, M. S., Raymond, D. A., Hanley, D. A., Boyd, S. K. (2019). Effect of High-Dose Vitamin D Supplementationon Volumetric Bone Density and Bone Strength. JAMA, 322(8), 736. DOI: https://doi.org/10.1001/ jama.2019.11889

Grant, W. B. (2011): An estimate of the global reduction in mortality rates through doubling vitamin D level. Eur J Clin Nutr. 65, 1016-1026. DOI: https:// doi.org/10.1038/ejcn.2011.68

Haykal, T., Samji, V., Zayed, Y., Gakhal, I., Veerapaneni, V., Obeid, M., Kheirl, B., Badami, S., BACHUWA, G., DANISH, R. (2019) Role of vitamin D supplementation for primary prevention of cancer: Meta-analysis of randomized controlled trials. Journal of Clinical Oncology, 37 (15_suppl): 1534. DOI: https://doi.org/10.1200/ JCO.2019.37.15_suppl.153

Hothorn, T., Hornik, K., van de Wiel, MA., Zeileis, A. (2006). A Lego System for Conditional Inference. The American Statistician, 60(3), 257-263.

Jopp, A. (2008). Veszedelmes vitaminhiány. Budapest: Bioenergetic Kiadó.

Lenz, T.L. (2009). Vitamin D Supplementation and Cancer Prevention. Am J Lifestyle Med. 3, 365-368. DOI: https://doi.org/10.1177/1559827609339280

Meyer D, Zeileis A, Hornik K (2006). vcd: Visualizing Categorical Data. R package version 1.0-6.

Michael F. PhD. Md. Holıck. (2012). A nélkülözhetetlen D-vitamin - A leggyakoribb egészségi probléma gyógyítása három lépésben. Budapest: Park Könyvkiadó Kft.

Murrell, P. (2002). The grid Graphics Package. R News, 2(2), 14-19.

MüHLeıı. F. (2003). Vitaminok - Fitten, szépen, egészségesen. Kaposvár: Holló és társa Kft.

Prietl, B., Treiber, G., Pieber, T., \& Amrein, K. (2013). Vitamin D and Immune Function. Nutrients, 5(7), 2502-2521. DOI: https://doi.org/10.3390/nu5072502

SzeBerényI J. (2014). Molekuláris biológia. Dialóg Campus Kiadó - Nordex Kft. 
TEAM, R. (2015). RStudio: integrated development for R. RStudio, Inc., Boston, MA URL http://www. rstudio. Com, 42, 14. (Letöltve: 2020. febr. 16-án)

Thomas, L. D. K., Elinder, C.- G., Tiselius, H.-G., Wolk, A., \& Åkesson, A. (2013). Ascorbic Acid Supplements and Kidney Stone Incidence Among Men: A Prospective Study. JAMA Internal Medicine, 173(5), 386. DOI: https://doi.org/10.1001/ jamainternmed.2013.2296

TuohimaA, P. (2008) Vitamin D, aging, and cancer. Nutr. Rev, 66, S147-S152. DOI: https://doi.org/10.1111/j.1753-4887.2008.00095.x

WHARTON, B., \& BISHOP, N. (2003). Rickets. The Lancet, 362(9393), 1389-1400. DOI: https://doi.org/10.1016/S0140-6736(03)14636-3 